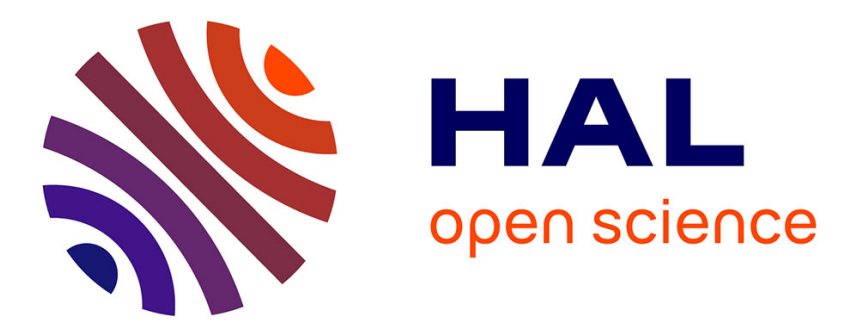

\title{
Microphase Separation of Polybutyrolactone-Based Block Copolymers with Sub-20 nm Domains
}

Franck Kayser, Guillaume Fleury, Somprasong Thongkham, Christophe Navarro, Blanca Martin-Vaca, Didier Bourissou

\section{- To cite this version:}

Franck Kayser, Guillaume Fleury, Somprasong Thongkham, Christophe Navarro, Blanca MartinVaca, et al.. Microphase Separation of Polybutyrolactone-Based Block Copolymers with Sub-20 nm Domains. Macromolecules, 2018, 51 (16), pp.6534 - 6541. 10.1021/acs.macromol.8b00739 . hal01938080

\section{HAL Id: hal-01938080 https://hal.science/hal-01938080}

Submitted on 2 Jul 2020

HAL is a multi-disciplinary open access archive for the deposit and dissemination of scientific research documents, whether they are published or not. The documents may come from teaching and research institutions in France or abroad, or from public or private research centers.
L'archive ouverte pluridisciplinaire HAL, est destinée au dépôt et à la diffusion de documents scientifiques de niveau recherche, publiés ou non, émanant des établissements d'enseignement et de recherche français ou étrangers, des laboratoires publics ou privés. 


\section{MICROPHASE SEPARATION OF POLYBUTYROLACTONE BASED BLOCK COPOLYMERS WITH SUB-20 nm DOMAINS}

Franck Kayser, ${ }^{a}$ Guillaume Fleury, ${ }^{b}$ Somprasong Thongkham, ${ }^{a}$ Christophe Navarro, ${ }^{c}$ Blanca Martin-Vaca, ${ }^{a, *}$ Didier Bourissou ${ }^{a, *}$

aUniversité de Toulouse, UPS, 118 route de Narbonne, F-31062 Toulouse, France and CNRS, LHFA UMR5069, F-31062 Toulouse, France.

bLaboratoire de Chimie des Polymères Organiques (LCPO), Université de Bordeaux, CNRS UMR 5629, IPB-ENSCBP, 16 Avenue Pey-Berland, F-33607 Pessac Cedex, France.

'ARKEMA, Groupement de Recherches de Lacq RN 117, BP 34, F-64170 Lacq Cedex, France.

\footnotetext{
ABSTRACT: Polybutyrolactone tri- and di-block copolymers with well-defined structures and narrow molar distributions were prepared by trifluoromethane sulfonic acid-organocatalyzed ringopening polymerization of $\beta$-butyrolactone initiated with dihydroxylated poly(hydrogenated)butadiene and hydroxylated polystyrene. Study of the phase separation behavior of these block copolymers in the bulk and in thin film shows their ability to segregate even for low molecular weights, giving rise to spherical, cylindrical and lamellar morphologies with periodicities in the range of 10-20 nm. Estimation of the Flory-Huggins interaction parameter form the order-to-disorder transition temperatures reveals values in the same range or higher than other block copolymers associating biodegradable and polyolefin blocks
} 


\section{INTRODUCTION}

The ability of block copolymers (BCPs) to self-assemble on the nanometer length scale into various morphological structures with segregated domains makes such materials valuable for an array of applications. ${ }^{1-3}$ Among them we can mention dispersant agents, ${ }^{4}$ nanoporous membranes, ${ }^{5}$ photovoltaics, ${ }^{6}$ and nanolithography, ${ }^{7,8}$ in which direct self-assembly (DSA) of BCPs has emerged as a solution for the production of nanostructured patterns beyond the limits of conventional optical lithography.

The propensity of BCPs for phase separation is governed by three main factors: the FloryHuggins interaction parameter $(\chi)$, the degree of polymerization $(N)$, and the relative volume fraction of each block that determine the segregation behavior. ${ }^{9,10}$ According to the mean-field theory, a symmetric $\mathrm{AB}$ diblock $\mathrm{BCP}\left(f_{\mathrm{A}}=f_{\mathrm{B}}=0.5\right)$ will segregate for values of $\chi N>10.5$. At lower values, the blocks tend to become miscible and the effect is more marked for mismatched volume fractions. Since the periodicity, $d$, follows the relation $d \sim \chi^{1 / 6} N^{2 / 3}$ in the strong segregation regime, ${ }^{11}$ achieving self-assembled structures with periodicity lower than $20 \mathrm{~nm}$ requires lowering the value of $N$ while increasing that of $\chi$ so that phase separation is still obtained. ${ }^{12}$

PS-b-PMMA are the reference BCPs for DSA applications and have been thoroughly evaluated towards integration in the lithographic industry. ${ }^{13}$ However, these BCPs are not suitable to achieve sub-20 nm periodic structures due to a relatively low $\chi$ value. ${ }^{14,15}$ This limitation, and the high interest of the scientific community to access sub-20 nm patterns, have stimulated intense efforts on the macromolecular engineering of "high" $\chi$ BCPs. ${ }^{16-24}$ Among the different families of BCPs that have been studied, we can highlight BCPs comprising a biodegradable polyester or polycarbonate block. ${ }^{25-34}$ The increased difference in polarity between the blocks results in higher $\chi$ than for PS- $b$-PMMA. ${ }^{12}$ In addition, the chemical structure of the biodegradable block permits 
its removal not only by dry-etching, but also by wet-etching using basic or enzymatic solutions. This allows selective removal since these conditions do not affect the less polar block. Polylactic acid (PLA) is the most investigated biodegradable block and its association with polydimethylsiloxane (PDMS) ${ }^{25}$ or polyolefins such as poly(ethylene-alt-propylene) (PEP), ${ }^{27}$ polystyrene (PS), ${ }^{28}$ polycyclohexylethylene (PCHE), ${ }^{30}$ polybutadiene (PBD) ${ }^{31}$ has been reported to produce BCP structures with sub-20 nm periodicities. In particular, sub-10 nm periodicities have been obtained for PDMS- $b$-PLA ${ }^{20,35}$ and PEP- $b$-PLA BCPs. ${ }^{27}$ Very recently, the ability to produce sub-20 nm patterns from BCPs combining PS with a polycarbonate block such as poly(trimethylene carbonate) (PTMC) or poly(propylene carbonate) (PPC) has also been reported, ${ }^{32-35}$ broadening the structural diversity of "high" $\chi$ BCPs containing a biodegradable block.

Poly(3-hydroxybutyrate) (PHB), also called polybutyrolactone (PBL) when prepared by ringopening polymerization (ROP) of $\beta$-butyrolactone, is a biodegradable polymer that has attracted high interest and found applications in medical and packaging sectors. ${ }^{37,38}$ In particular PBL has been included in BCPs with other biodegradable blocks (PLA, poly( $\varepsilon$-caprolactone) (PCL)) seeking to modulate their mechanical properties, ${ }^{39,40}$ or with poly(ethylene glycol) (PEG) aiming at preparing amphiphilic BCPs. ${ }^{41}$ In marked contrast, BCPs combining a PBL block with polyolefins are almost unprecedented. The sole example, for which phase segregation has been discussed, consists in a PS- $b$-PBL- $b$-PS triblock copolymer $\left(M_{\mathrm{n}}=8400 \mathrm{~g} / \mathrm{mol}\right)$ which selfassembles into a lamellar morphology with a periodicity of $40 \mathrm{~nm} .{ }^{42}$ The high molecular distribution of the central PBL block, prepared by transterification of a PBL of high $M_{\mathrm{n}}$ with EtOH, results in a relatively high molecular distribution of the BCP $(\nexists=1.58)$ leading to a large periodicity of the segregated BCP..$^{43,44}$ 
The impressive progress achieved over the last decade in organocatalyzed ROP of lactones and cyclic carbonates opens the way to metal-free controlled preparation of well-defined BCPs bearing at least one biodegradable block, thanks to the efficiency of ROP initiation of these cyclic monomers using hydroxyl-terminated polymers (macro-initiators). ${ }^{45-47}$ This technology is now mature and can be applied to the preparation of BCP with blocks of diverse nature with the aim to further broaden the family of BCPs capable to segregate into morphologies with sub-20 nm periodicities. Most interestingly, trifluoromethane sulfonic acid (HOTf ) has been reported as the sole metal-free catalyst capable to promote the ROP of $\beta$-BL with selective $O$-acyl ring opening and high initiator incorporation, leading to PBL with well-defined chain ends and low molecular distributions. ${ }^{48,48}$ Thanks to this behavior, HOTf is the ideal catalyst for the preparation of BCPs of PBL using hydroxylated macro-initiators. Indeed, we report here that the ROP of PBL promoted by HOTf, using dihydroxylated PBD, hydrogenated-PBD (PBD H) and monohydroxylated PS as macro-initiators, permits the controlled preparation of polybutyrolactone- $b$-polybutadiene- $b$ polybutyrolactone (PBL-b-PBD- $b$-PBL), polybutyrolactone- $b$-poly(hydrogenated-butadiene)- $b$ polybutyrolactone (PBL- $b$-PBD H-b-PBL) triblock and PS- $b$-PBL diblock copolymers. Most remarkably, these BCPs of low molecular distributions are able to segregate into nanostructures of lamellar, cylindrical or spherical morphologies with periodicities in the range $10-20 \mathrm{~nm}$. The nanostructuration was evidenced by Small Angle X-ray Scattering (SAXS) analyses in the bulk and by Scanning Electron microscopy (SEM) / Atomic Force Microscopy (AFM) analyses in thin films. In addition, determination of the order-disorder transition temperatures (TODT) by Dynamic Mechanical Analysis (DMA) allowed for the estimation of the Flory-Huggins interaction parameter. 


\section{EXPERIMENTAL SECTION}

Materials. All reactions were performed under an inert atmosphere of argon, using standard Schlenk techniques. Toluene (>99.9\%) was dried prior to use with a Braun solvent-purifier system. $\beta$-BL (98\%, Aldrich) was purified by distillation over $\mathrm{CaH}_{2}$ and stored under argon. The trifluoromethane sulfonic acid (HOTf) (98\%, Aldrich) was used as received and stored under argon. Solutions of Polybutadiene, PBD, macro-initiator (Krasol LBH-P3000®, Krasol HLBHP2000®, and Krasol HLBH-P3000®, Cray Valley) in dichloromethane were prepared to dry the macro-initiator by addition of molecular sieves. Once the solutions filtered, the solvent was evaporated and the macro-initiators were dried over phosphorous pentoxide before use. Polystyrene macro-initiator (PS-OH, Scientific Polymer Products, Inc.) was dried over phosphorous pentoxide before use.

\section{Characterization Methods}

SEC analyses. The number-average and weight-average molar masses ( $M_{\mathrm{n}}$ and $M_{\mathrm{w}}$, respectively) and molar mass distributions $(\bigoplus)$ of the polymer samples were determined by size exclusion chromatography (SEC) at $35^{\circ} \mathrm{C}$ with a Waters 712 WISP high-speed liquid chromatograph equipped with a R410 refractometer detector. Tetrahydrofuran (THF) was used as the eluent and the flow rate was set up at $1.0 \mathrm{~mL} / \mathrm{min}$. A SHODEX pre-column (polystyrene AT806M/S $M_{\mathrm{w}}=$ $50000000 \mathrm{~g} / \mathrm{mol}$ ) and two STYRAGEL columns (HR1, 100 - $5000 \mathrm{~g} / \mathrm{mol}$ and HR 4E, 50 $100000 \mathrm{~g} / \mathrm{mol}$ ) were used. Calibrations were performed using polystyrene standards (400 $100000 \mathrm{~g} / \mathrm{mol})$.

${ }^{1} \mathrm{H}$ NMR Analyses. NMR Spectra were recorded in $\mathrm{CDCl}_{3}$ or $\mathrm{C}_{6} \mathrm{D}_{6}$ on BRUKER Avance 300, 400 and $500 \mathrm{MHz}$ spectrometers at room temperature and chemical shifts are reported in ppm relative 
to $\mathrm{Me}_{4} \mathrm{Si}$ as an external standard. ${ }^{1} \mathrm{H}$ measurements were used to determine the monomer conversion, the NMR degree of polymerization ( $\mathrm{DP}_{\mathrm{NMR}}$ ), and the end group fidelity. $\beta-\mathrm{BL}$ conversion was determined from the relative intensities of the $\mathrm{OCH}$ signals for the monomer (multiplet at $\delta=3.66 \mathrm{ppm}$ ) and polymer (multiplet at $\delta=5.32 \mathrm{ppm}$ ). $\mathrm{DP}_{\mathrm{NMR}}$ was determined from the relative intensities of the $\mathrm{OCH}$ signals for polymer (multiplet at $\delta=5.32 \mathrm{ppm}$ ) and the terminal $\mathrm{CHOH}$ signal (multiplet at $\delta=4.31 \mathrm{ppm}$ ). The end group fidelity was determined from the relative intensities of the macro-initiator and the terminal $\mathrm{CHOH}$ signal.

Differential Scanning Calorimetry. The thermal properties of the polymers were measured on a NETZCH DSC 204 system, under a nitrogen atmosphere at heating and cooling rates of 20 and $10^{\circ} \mathrm{C} \cdot \mathrm{min}^{-1}$, respectively. The $T_{\mathrm{g}}$ values were extracted from the second heating curves.

Thermal gravimetric analysis. The thermal stability of the polymers was measured on a PERKIN ELMER DIAMOND TG/TDA thermobalance, under air from 25 to $650^{\circ} \mathrm{C}$ at a heating rate of $20^{\circ} \mathrm{C} / \mathrm{min}$. The degradation temperatures correspond to the temperature from which the curves switched off the baseline.

SAXS Analysis. SAXS experiments at room temperature were performed from the polymer powder after thermal annealing at $100^{\circ} \mathrm{C}$ for $12 \mathrm{~h}$. SAXS profiles were acquired in transmission on a Nanostar-U instrument (Bruker AXS) with a copper anode source. The resulting 2-D images were found to be isotropic, and the data were azimuthally averaged to yield curves of the scattering intensity versus $q=(4 \pi / \lambda) \sin (\theta)$, where $\lambda=1.54 \AA$ is the wavelength of the $\mathrm{Cu} \mathrm{K} \alpha$ radiation and $\theta$ is half the scattering angle.

Variable temperature SAXS experiments were performed either on the Dutch-Belgian Beamline (DUBBLE) or on the D2AM French-CRG Beamline at the European Synchrotron Radiation 
Facility (ESRF) station BM26B in Grenoble, France. On the DUBBLE Beamline, a Pilatus 1M detector was used for recording the 2D scattering images and a $2000 \mathrm{~mm}$ sample-to-detector distance was chosen. The energy of the X-ray beam was $12 \mathrm{keV}$. On the D2AM French-CRG Beamline, a XPAD 2D pixel detector was used for recording the 2D scattering images and a 2400 mm sample-to-detector distance was chosen. The energy of the X-ray beam was $11 \mathrm{keV}$. The 2D images were radially averaged around the center of the primary beam in order to obtain the isotropic SAXS intensity profiles. The scattering pattern from a specimen of silver behenate was used for the calibration of the wavevector scale of the scattering curves. Finally, the data were normalized to the intensity of the incident beam in order to correct for primary beam intensity fluctuations.

Dynamical mechanical analysis. Viscoelastic data were obtained from the copolymers by dynamical mechanical spectroscopy using an Anton Paar MCR 302 rheometer fitted with 8 mm diameter parallel plates. All measurements were conducted under a nitrogen atmosphere in the linear viscoelastic regime, as determined from dynamic strain sweep tests performed at $100^{\circ} \mathrm{C}$. The dynamic elastic $\left(G^{\prime}\right)$ and loss $\left(G^{\prime \prime}\right)$ moduli were measured as a function of temperature at a frequency $\omega=1 \mathrm{rad} . \mathrm{s}^{-1}$ and a strain $\gamma=5 \%$; these experiments, referred to as isochronal temperature ramp tests $\left(2.5^{\circ} \mathrm{C} / \mathrm{min}\right)$, were employed to search for order-disorder or other phase transitions.

Self-assembly of block copolymer thin film. Block copolymers thin films were prepared by spincoating from PGMEA/tetrahydrofuran solutions $(0.5-4 \% \mathrm{w} / \mathrm{w})$ and the film thickness was controlled by varying the spin coating speed (0.5-2 krpm). The self-assembly of block copolymers was promoted by thermal annealing of samples, which were placed on a hot plate with a typical 
temperature range of $70-190^{\circ} \mathrm{C}$ or by vapor solvent treatment (THF/MeOH, 2/1) for $2 \mathrm{~h}$. Film thickness was determined optically by reflectometry.

Plasma Etching. Prior to SEM/AFM analyses, PBL-b-PBD- $b$-PBL and PS- $b$-PBL thin films were respectively etched with $\mathrm{O}_{2}$ and a fluorine-rich RIE treatment using a plasma etch tool (PE-100, PlasmaEtch) in order to remove preferentially the PBL phase (downstream plasma with $25 \mathrm{sccm}$ $\mathrm{O}_{2}$, 500W, 100 mTorr for PBL-b-PBD-b-PBL and 17 sccm CF 4 and 3 sccm $\mathrm{O}_{2}, 40 \mathrm{~W}, 180$ mTorr for PS-b-PBL).

AFM Characterization. Atomic force microscopy (AFM, Dimension FastScan, Bruker) was used in tapping mode to characterize the surface morphology of BCP thin films. Silicon cantilevers (Fastscan-A) with a typical radius of $\sim 5 \mathrm{~nm}$ were used. The resonance frequency of the cantilevers was about $1.25 \mathrm{kHz}$. All AFM measurements were conducted at $22^{\circ} \mathrm{C}$.

SEM Characterization. Top-view SEM images of BCP thin films were recorded on a Critical Dimension SEM (CD-SEM) H9300 from Hitachi, with a beam operating at $800 \mathrm{~V}$ and $0.6 \mathrm{pA}$ as extraction current, allowing $\times 100 \mathrm{~K}$ or $\times 300 \mathrm{~K}$ magnifications.

\section{Synthesis of the block copolymers}

Typical procedure for the preparation of $P B L_{37}-b-P B D_{65}-b-P B L_{37} . \beta-B L(4.60 \mathrm{~g}, 53.5 \mathrm{mmol}, 80$ eq.) and macro-initiator (Krasol LBH-P3000®, Cray Valley, 2.35 g, 0.67 mmol, 1 eq.) were weighted under controlled atmosphere. The solvent $\left(14 \mathrm{~mL}\right.$ of toluene, $\left.[\beta-\mathrm{BL}]_{0}=4 \mathrm{~mol} / \mathrm{L}\right)$ and the catalyst (trifluoromethane sulfonic acid, $168 \mu \mathrm{L}, 1.34 \mathrm{mmol}, 2$ eq.) were successively added. The reaction mixture was stirred at $30^{\circ} \mathrm{C}$ for $2 \mathrm{~h} 30$ until the complete consumption of $\beta$-BL, as 
determined by ${ }^{1} \mathrm{H}$ NMR spectroscopy. An excess of diisopropylethylamine was added to neutralize the catalyst, and the solvent was evaporated under vacuum. The block copolymer was then dissolved in a minimum of dichloromethane and precipitated in cold methanol, then filtered and dried under vacuum. Conversion: 99\%; Yield: 92\%; SEC: $M_{\mathrm{n}}=12000 \mathrm{~g} / \mathrm{mol} ; \ni=1.19$; DSC: $T_{\mathrm{g}}$ $=-39.9^{\circ} \mathrm{C}$ and $-17.4^{\circ} \mathrm{C}$; ATG: $T_{\mathrm{d}}=276^{\circ} \mathrm{C} ;{ }^{1} \mathrm{H}$ NMR $\left(\mathrm{CDCl}_{3}, 300 \mathrm{MHz}\right): 5.55-5.30(\mathrm{~m}, 40 \times 1 \mathrm{H}$, $\left.\mathrm{CHCH}=\mathrm{CH}_{2}, \quad 2 \times 10 \times 2 \mathrm{H}, \quad \mathrm{CHCH}=\mathrm{CHCH}, \quad 74 \times 1 \mathrm{H} \quad \mathrm{CH}\left(\mathrm{CH}_{3}\right) \mathrm{O}(\mathrm{C}=\mathrm{O})\right), \quad 5.00-4.80 \quad(\mathrm{~m}$, $\left.40 \times 2 \mathrm{H}, \mathrm{CHCH}=\mathrm{CH}_{2}\right), 4.30-4.00\left(\mathrm{~m}, 2 \times 1 \mathrm{H}, \mathrm{CH}\left(\mathrm{CH}_{3}\right) \mathrm{OH}\right.$ chain end, $2 \times 2 \mathrm{H}, \mathrm{CH}_{2} \mathrm{O}$ initiator), 2.70$2.40\left(\mathrm{~m}, 74 \times 2 \mathrm{H},(\mathrm{C}=\mathrm{O}) \mathrm{CH}_{2}\right), 2.20-1.75\left(\mathrm{~m}, 40 \times 1 \mathrm{H}, \mathrm{CHCH}=\mathrm{CH}_{2}, 2 \times 10 \times 4 \mathrm{H},-\mathrm{CH}_{2}-\mathrm{CH}=\mathrm{CH}-\mathrm{CH}_{2}-\right.$ ), 1.45-1.10 (m, 74×3H, $\left.\mathrm{CH}\left(\mathrm{CH}_{3}\right) \mathrm{O}(\mathrm{C}=\mathrm{O}), 40 \times 2 \mathrm{H}, \mathrm{CH}_{2}-\mathrm{CH}_{2}-\mathrm{CH}\right)$.

Typical procedure for the preparation of $P B L_{54}-b-P B D H_{55}-b-P B L_{54} . \beta-B L(1.71 \mathrm{~g}, 19.9 \mathrm{mmol}$, 120 eq.) and PBD H macro-initiator (Krasol HLBH-P3000®, Cray Valley, 0.50 g, 0.16 mmol, 1 eq.) were weighted under controlled atmosphere. The solvent $\left(4.8 \mathrm{~mL}\right.$ of toluene, $[\beta-\mathrm{BL}]_{0}=4$ $\mathrm{mol} / \mathrm{L}$ ) and the catalyst (trifluoromethane sulfonic acid, $29 \mu \mathrm{L}, 0.32 \mathrm{mmol}, 2$ eq.) were successively added. The reaction mixture was stirred at $30^{\circ} \mathrm{C}$ for $3 \mathrm{~h} 30$ until the complete consumption of $\beta$-BL, as determined by ${ }^{1} \mathrm{H}$ NMR spectroscopy. An excess of diisopropylethylamine was added to neutralize the catalyst, and the solvent was evaporated under vacuum. The block copolymer was then dissolved in a minimum of dichloromethane and precipitated in cold methanol, then filtered and dried under vacuum. Conversion: 99\%; Yield: 96\%; SEC: $M_{\mathrm{n}}=15800 \mathrm{~g} / \mathrm{mol}, \nexists=1.20$; DSC: $T_{\mathrm{g}}=-52.4^{\circ} \mathrm{C}$ and $-4.3^{\circ} \mathrm{C}$; TGA: $T_{\mathrm{d}}=312^{\circ} \mathrm{C} ;{ }^{1} \mathrm{H}$ NMR $\left(\mathrm{CDCl}_{3}, 300 \mathrm{MHz}\right)$ : 5.35-5.15 (m, 108×1H $\left.\mathrm{CH}\left(\mathrm{CH}_{3}\right) \mathrm{O}(\mathrm{C}=\mathrm{O})\right), 4.30-4.00(\mathrm{~m}, 2 \times 1 \mathrm{H}$, $\mathrm{CH}\left(\mathrm{CH}_{3}\right) \mathrm{OH}$ chain end, $2 \times 2 \mathrm{H}, \mathrm{CH}_{2} \mathrm{O}$ initiator), $2.70-2.40\left(\mathrm{~m}, 108 \times 2 \mathrm{H}, \mathrm{COCH}_{2}\right), 1.45-0.95(\mathrm{~m}$, $36 \times 1 \mathrm{H}, \quad \mathrm{CH}_{2}-\mathrm{CH}-\mathrm{CH}_{2}, \quad 2 \times 36 \times 2 \mathrm{H}, \quad \mathrm{CH}-\mathrm{CH}_{2}-\mathrm{CH}_{3}, \quad 2 \times 10 \times 8 \mathrm{H}, \quad-\mathrm{CH}_{2}-\mathrm{CH}_{2}-\mathrm{CH}_{2}-\mathrm{CH}_{2}-, \quad 108 \times 3 \mathrm{H}$, $\left.\mathrm{CH}\left(\mathrm{CH}_{3}\right) \mathrm{O}(\mathrm{C}=\mathrm{O})\right), 0.95-0.75\left(\mathrm{~m}, 36 \times 3 \mathrm{H}, \mathrm{CH}_{2}-\mathrm{CH}_{3}\right)$. 
Typical procedure for the preparation of $P S_{100}-b-P B L_{43} . \beta-B L(0.335 \mathrm{~g}, 3.89 \mathrm{mmol}, 60 \mathrm{eq}$.$) and$ macro-initiator (PS100-OH, Scientific Polymer Products, Inc. , 0.60 g, 0.07 mmol, 1 eq.) were weighted under controlled atmosphere. The solvent ( $4 \mathrm{~mL}$ of toluene, $\left.[\beta-\mathrm{BL}]_{0}=1 \mathrm{~mol} / \mathrm{L}\right)$ and the catalyst (trifluoromethane sulfonic acid, $6 \mu \mathrm{L}, 0.07 \mathrm{mmol}, 1$ eq.) were successively added. The reaction mixture was stirred at $30^{\circ} \mathrm{C}$ for $2 \mathrm{~h} 30$ until the complete consumption of $\beta$-BL, as determined by ${ }^{1} \mathrm{H}$ NMR spectroscopy. An excess of diisopropylethylamine was added to neutralize the catalyst, and the solvent was evaporated under vacuum. The block copolymer was then dissolved in a minimum of dichloromethane and precipitated in cold methanol, then filtered and dried under vacuum. Conversion: 83\%; Yield: 75\%; SEC: $M_{\mathrm{n}}=11300 \mathrm{~g} / \mathrm{mol}, \nexists=1.12$; DSC: $T_{\mathrm{g}}$ $=75.8^{\circ} \mathrm{C}$ and $-0.3^{\circ} \mathrm{C}$; TGA: $T_{\mathrm{d}}=262^{\circ} \mathrm{C} ; 1 \mathrm{H} \mathrm{NMR}\left(\mathrm{CDCl}_{3}, 300 \mathrm{MHz}\right): 7.40-6.90(\mathrm{~m}, 100 \times 3 \mathrm{H}$, Ph), 6.90-6.25 $(100 \times 2 \mathrm{H}, \mathrm{Ph}), 5.35-5.15\left(\mathrm{~m}, 43 \times 1 \mathrm{H} C H\left(\mathrm{CH}_{3}\right) \mathrm{O}(\mathrm{C}=\mathrm{O})\right), 4.30-4.00(\mathrm{~m}, 2 \times 1 \mathrm{H}$, $\mathrm{CH}\left(\mathrm{CH}_{3}\right) \mathrm{OH}$ chain end, $2 \times 2 \mathrm{H}, \mathrm{CH}_{2} \mathrm{O}$ initiator), 2.70-2.40 (m, 43×2H, (C=O)CH $), 2.20-1.20(\mathrm{~m}$, $\left.100 \times 1 \mathrm{H}, \mathrm{CH}_{2} \mathrm{CHPh}, 100 \times 2 \mathrm{H}, \mathrm{CH}_{2} \mathrm{CHPh}, 43 \times 3 \mathrm{H}, \mathrm{CH}\left(\mathrm{CH}_{3}\right) \mathrm{O}(\mathrm{C}=\mathrm{O})\right), 0.80-0.50\left(\mathrm{~m}, 3 \mathrm{H}, \mathrm{CH}_{3}-\mathrm{CH}\right.$, $\left.3 \mathrm{H} \mathrm{CH}_{3}-\mathrm{CH}_{2}-\mathrm{CH}\right)$. 


\section{RESULTS AND DISCUSSION}

Copolymer preparation and characterization. Recently, we reported HOTf as the sole metalfree efficient promoter for the ROP of $\beta$-BL in the presence of an alcohol as initiator. ${ }^{49}$ Controlled polymerization via $O$-acyl bond-cleavage takes place leading to high end-group fidelity with full incorporation of the protic initiator. The feasibility of the initiation with a (di)hydroxylated macroinitiator such as PBD $\left(\mathrm{Krasol}^{\circledR}\right)$ was also demonstrated. We have therefore used HOTf as catalyst for the metal-free preparation of the triblock copolymers using PBD and PBD H as dihydroxylated macro-initiators. We also examined the formation of diblock BCP architecture using monohydroxylated PS as macro-initiator (Scheme 1). The reactions were carried out at $30-60^{\circ} \mathrm{C}$ in toluene at different $\beta$-BL/macro-initiator ratios so that $\mathrm{BCPs}$ of different volume fractions were obtained. At the end of the reaction, the HOTf catalyst was removed from the reaction media by simple addition of diisopropylethyl amine (DIEA). Precipitation from cold methanol allows to recover the BCP materials in 75-96 \% yield.

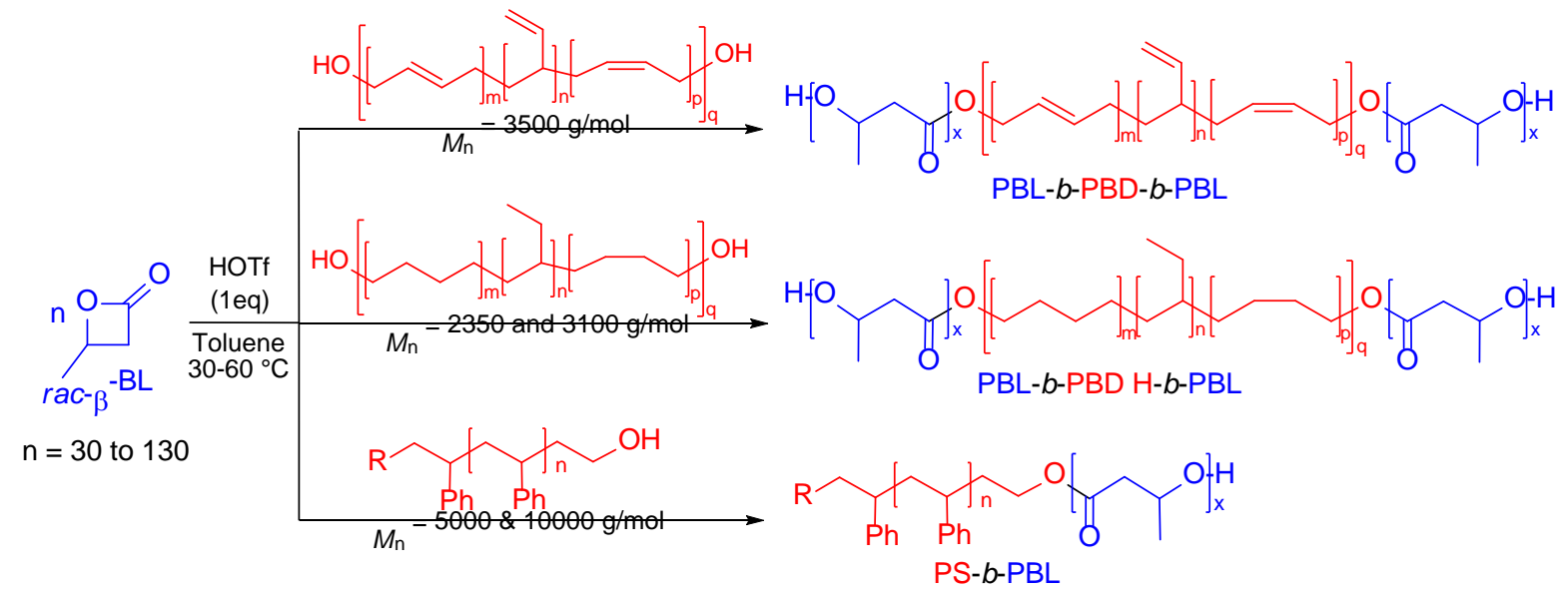

Scheme 1. Preparation of the PBL- $b$-PBD- $b$-PBL and PBL- $b$-PBD H- $b$-PBL triblock and PS- $b$ PBL diblock copolymers 
Table 1. NMR, SEC, DSC and SAXS analyses of the PBL/PBD (H) and PBL/PS BCP

\begin{tabular}{|c|c|c|c|c|c|c|c|c|c|c|}
\hline $\mathrm{M} / \mathrm{I}^{\mathrm{a}}$ & Conv. ${ }^{\mathrm{b}}$ & $M_{\text {nthéo. }}{ }^{c}$ & $M_{\mathrm{nNMR}}^{\mathrm{d}}$ & $M_{\mathrm{nSEC}}{ }^{\mathrm{e}}$ & $\oslash^{\mathrm{e}}$ & Composition $^{\mathrm{d}}$ & $f_{\mathrm{BL}}{ }^{\mathrm{f}}$ & $T_{\mathrm{g} 1}{ }^{\mathrm{g}}$ & $T_{\mathrm{g} 2} \mathrm{~g}$ & $\begin{array}{l}\text { SAXS } \\
\mathrm{M}^{\mathrm{h}} \mathrm{d}^{\mathrm{i}}\end{array}$ \\
\hline 40 & 0.94 & 10000 & 9900 & 12000 & 1.19 & $\mathrm{PBL}_{37}-b-\mathrm{PBD}_{65}-b-\mathrm{PBL}_{37}$ & 0.57 & -39.9 & -17.7 & L 10.5 \\
\hline 80 & 0.99 & 17100 & 16400 & 18000 & 1.15 & $\mathrm{PBL}_{75}-b-\mathrm{PBD}_{65}-b-\mathrm{PBL}_{75}$ & 0.73 & -40.5 & -10.8 & C 14.7 \\
\hline 32 & 0.99 & 5102 & 5388 & 6500 & 1.11 & $\mathrm{PBL}_{17}-b-\mathrm{PBD} \mathrm{H} \mathrm{H}_{42}-b-\mathrm{PBL}_{17}$ & 0.48 & n. d. & n. d. & n. d. \\
\hline 30 & 0.99 & 8200 & 7500 & 10000 & 1.18 & $\mathrm{PBL}_{25}-b-\mathrm{PBD} \mathrm{H}_{55}-b-\mathrm{PBL}_{25}$ & 0.50 & -50.0 & -15.3 & L 12.1 \\
\hline 40 & 0.99 & 9900 & 9100 & 14500 & 1.14 & $\mathrm{PBL}_{35}-b-\mathrm{PBD} \mathrm{H}_{55}-b-\mathrm{PBL}_{35}$ & 0.59 & -49.5 & -7.1 & L 13.7 \\
\hline 60 & 0.98 & 13200 & 12400 & 15800 & 1.20 & $\mathrm{PBL}_{54}-b-\mathrm{PBD} \mathrm{H}_{55}-b-\mathrm{PBL}_{54}$ & 0.69 & -52.4 & -4.3 & C 15.8 \\
\hline 20 & 0.85 & 6300 & 6100 & 6700 & 1.07 & $\mathrm{PS}_{45}-b-\mathrm{PBL}_{15}$ & 0.19 & -0.3 & 56.4 & Dis \\
\hline 40 & 0.90 & 7724 & 6800 & 8000 & 1.13 & $\mathrm{PS}_{45}-b-\mathrm{PBL}_{34}$ & 0.35 & -0.3 & 58.2 & Dis \\
\hline 60 & 0.81 & 9000 & 8800 & 9000 & 1.09 & $\mathrm{PS}_{45}-b-\mathrm{PBL}_{65}$ & 0.48 & -0.2 & 58.3 & n.c. \\
\hline 60 & 0.83 & 14700 & 14100 & 11300 & 1.13 & $\mathrm{PS}_{100}-b-\mathrm{PBL}_{43}$ & 0.24 & -0.3 & 75.8 & n.c. \\
\hline 130 & 0.85 & 20300 & 19900 & 14500 & 1.19 & $\mathrm{PS}_{100}-b-\mathrm{PBL}_{110}$ & 0.44 & -0.7 & 76.5 & n.c. 22 \\
\hline
\end{tabular}

${ }^{\mathrm{a} S t a n d a r d ~ r e a c t i o n ~ c o n d i t i o n s: ~ H O T f ~}(1$ equiv. $)$, toluene $\left([\beta-\mathrm{BL}]_{0}=4 \mathrm{~mol} / \mathrm{L}\right), 30^{\circ} \mathrm{C} .{ }^{\mathrm{b}}$ Determined by ${ }^{1} \mathrm{H}$ NMR. ${ }^{\mathrm{c} C a l c u l a t e d ~ t a k i n g ~ i n t o ~ a c c o u n t ~ t h e ~ m o n o m e r ~ c o n v e r s i o n . ~}{ }^{\mathrm{d}}$ Determined by ${ }^{1} \mathrm{H}$ NMR using $M_{\mathrm{n} \text { PBD }}=3500 \mathrm{~g} / \mathrm{mol}$ and $M_{\mathrm{n} \text { PBD H }}=2350$ and $3100 \mathrm{~g} / \mathrm{mol} ; M_{\mathrm{n} \text { PS45 }}=4800 \mathrm{~g} / \mathrm{mol}$ and $M_{\mathrm{n}}$ ${ }_{\mathrm{PS} 100}=8100 \mathrm{~g} / \mathrm{mol}$. ${ }^{e}$ Determined by SEC with PS calibration. ${ }^{\mathrm{f}}$ Calculated using $d_{\mathrm{PBL}}=1.21, d_{\mathrm{PBD}}$ $=0.89, d_{\mathrm{PBD} \mathrm{H}}=0.88$ and $d_{\mathrm{PS}}=1.05$ (density values at $25^{\circ} \mathrm{C}$ ). ${ }^{\mathrm{g}}$ Determined by DSC. ${ }^{\mathrm{h}} \mathrm{M}$ : morphology, L: lamellar, C: cylindrical, Dis: disordered, n.d.: not determined, n.c.: not conclusive. ${ }^{\mathrm{i}}$ periodicity of the BCP structure. 


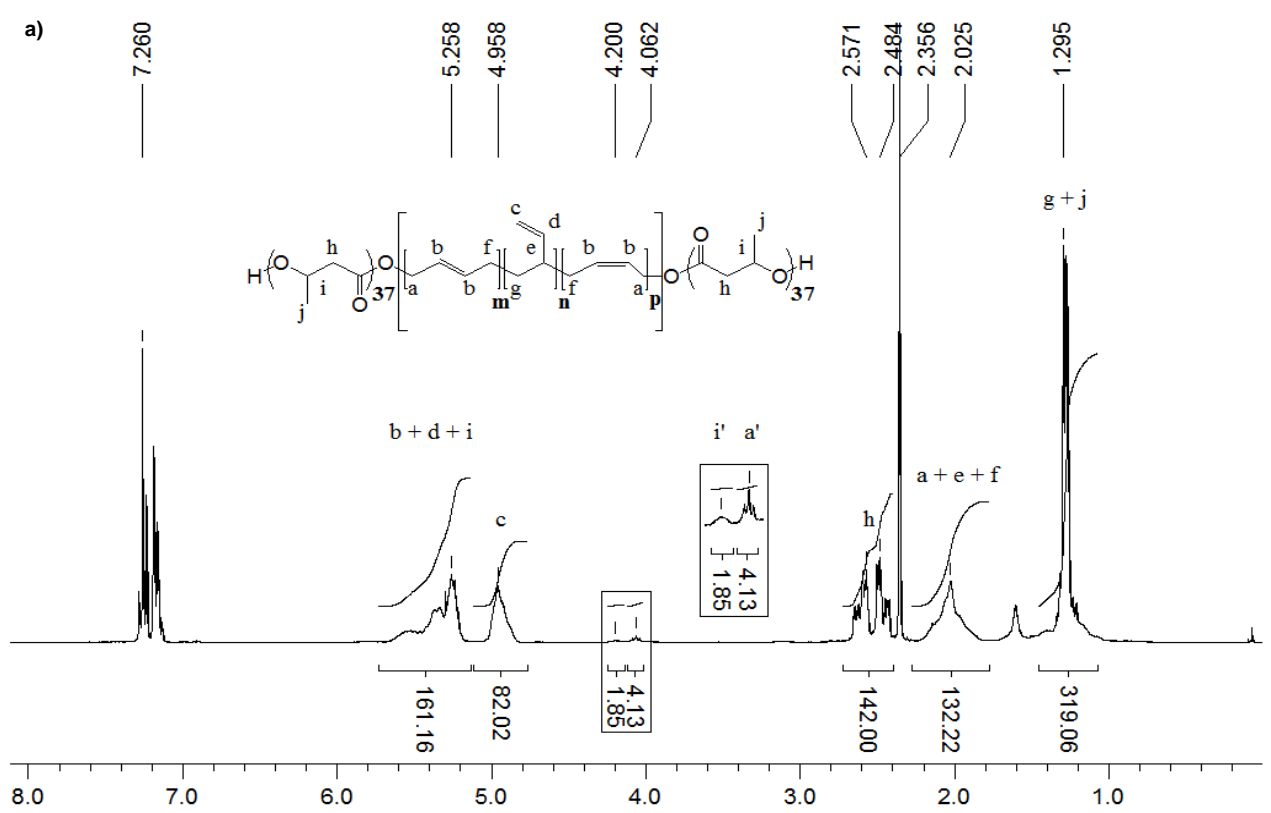

b)
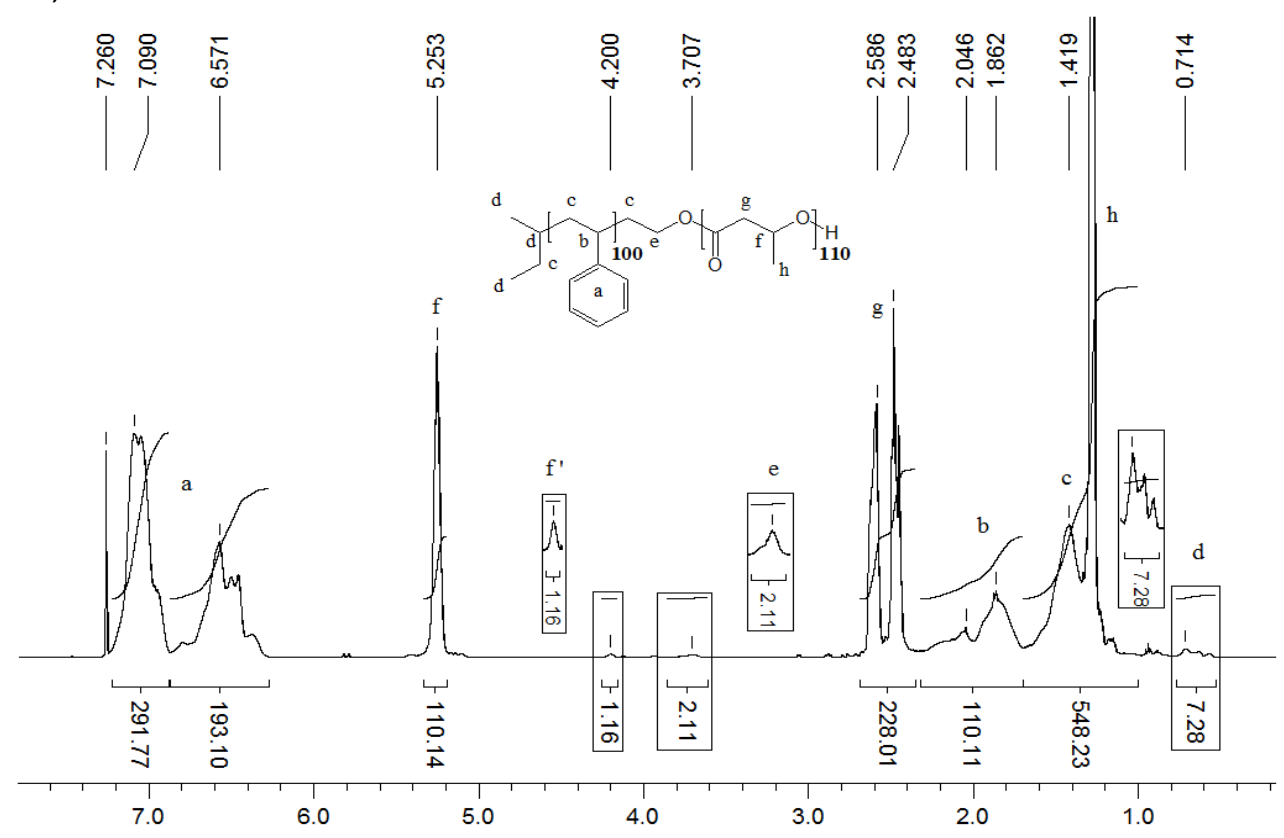

Figure 1. ${ }^{1} \mathrm{H}$ NMR spectra of (a) $\mathrm{PBL}_{37}-b-\mathrm{PBD}_{65}-b-\mathrm{PBL}_{37}$ and (b) $\mathrm{PS}_{100}-b-\mathrm{PBL}_{110}$

${ }^{1} \mathrm{H}$ NMR spectroscopy confirmed the chain-end fidelity and the $M_{\mathrm{n}}$ control of the BCP (Figures 1a and 1b). Efficient and exclusive initiation from the macro-initiator is supported by the disappearance of signals corresponding to the $\mathrm{CH}_{2} \mathrm{OH}$ groups of the macro-initiators $(3.75,3.50$ 
and 3.65 ppm for PBD, PBD H and PS, respectively), and the presence of a multiplet signal at lower field (4.05, 4.07 and $4.00 \mathrm{ppm}$, respectively) integrating for $4 \mathrm{H}$ in the case of PBD $\mathrm{H}$ and $2 \mathrm{H}$ in the case of PS, corresponding to the $\mathrm{CH}_{2} \mathrm{OCO}$ ester linkages. Calibration of the ${ }^{1} \mathrm{H}$ NMR spectra at one of the multiplet signal of the macro-initiator reveals a 2/1 relative integration between these $\mathrm{CH}_{2}$ ester signals and the $\mathrm{CHOH}$ terminal signal at $4.19 \mathrm{ppm}$, in agreement with the absence of competitive initiation or termination processes. These calibration leads also to degree of polymerization (DP) values in good agreement with the targeted ones (taking into account the monomer conversion). SEC analysis are also fully consistent with the initiation efficiency, with a noticeable increase of the $M_{\mathrm{n}}$ as regards to the macro-initiator (Fig S1-3) and with the controlled polymerization as the molecular distributions are narrow $(\nexists<1.20)$.

Thermal properties. The thermal properties of the BCPs were evaluated by thermogravimetric analysis (TGA) and differential scanning calorimetry (DSC). According to TGA, the copolymers undergo a two-phase stepwise thermal decompositions, in good agreement with their block architecture and with the monomer composition. The first degradation onset begins at $\sim 250^{\circ} \mathrm{C}$ and is associated with the PBL block (Figures S4-S6). The degradation temperature is consistent with an amorphous PBL included in a BCP architecture. ${ }^{42,50}$ DSC analysis of the BCPs (Figure 2) allowed for the estimation of their tendency to segregate in the bulk. Most of the samples feature two $T_{\mathrm{g}}$ values, each one close to the $T_{\mathrm{g}}$ of the respective homopolymers. The $T_{\mathrm{g}}$ of the PBL block ranges from $-17^{\circ} \mathrm{C}$ to $-0.2^{\circ} \mathrm{C}$, depending on the length of the block (indicating that the $M_{\mathrm{n}}$ are below or close to the value at which $T_{\mathrm{g}}$ levels off). ${ }^{51}$ The $T_{\mathrm{g}}$ of the PBD and PBD H blocks ( $40^{\circ} \mathrm{C}$ and $\sim-50^{\circ} \mathrm{C}$, respectively) are higher by c.a. $15^{\circ} \mathrm{C}$ with respect to the homopolymers (-55.4 and $-68.8^{\circ} \mathrm{C}$, respectively), probably due to the central position of these blocks in the BCPs, which reduces the mobility of the chains. In marked contrast, the $T_{\mathrm{g}}$ of PS is significantly decreased in 
the BCPs with PBL (from 90 to $56^{\circ} \mathrm{C}$ for $\mathrm{PS}_{45}$ and $\mathrm{PS}_{50}$, and from 97 to $75^{\circ} \mathrm{C}$ for $\mathrm{PS}_{100}$ ). This can be attributed to the length of the PS blocks which are below to the value at which $T_{\mathrm{g}}$ levels off, ${ }^{52}$ and to the increased mobility of the chains induces by the PBL block, which is of markedly lower $T_{\mathrm{g}}$. No melting isotherm related to the PBL block was observed, indicating its amorphous character, in line with the use of $r a c-\beta-B L$ as monomer. ${ }^{53}$
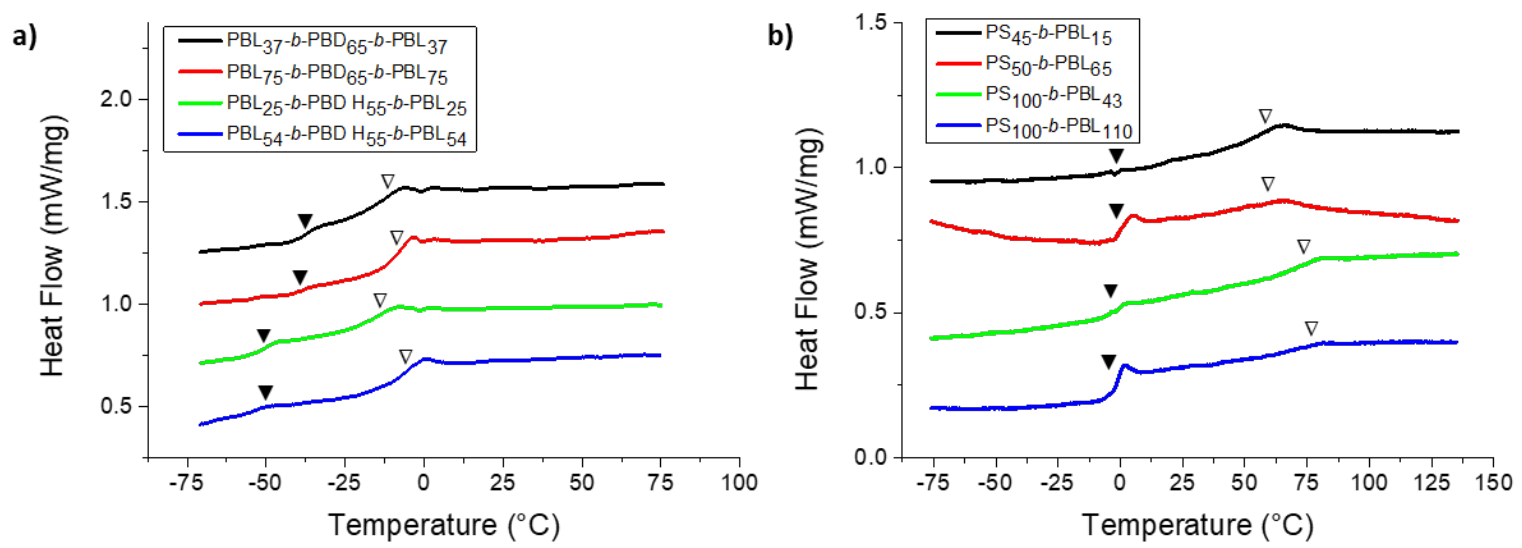

Figure 2. DSC traces of (a) PBL- $b$-PBD- $b$-PBL and PBL- $b$-PBD H- $b$-PBL triblock and PS- $b$-PBL diblock copolymers. Samples were heated at $20^{\circ} \mathrm{C} / \mathrm{min}$ and cooled at $10^{\circ} \mathrm{C} / \mathrm{min}$. Traces correspond to the second heating cycle.

Microphase segregation in the bulk. The PBL-containing BCP bulk phase behavior was probed by SAXS. All samples were thermally annealed at $100^{\circ} \mathrm{C}$ overnight prior to analysis. SAXS patterns obtained at $25^{\circ} \mathrm{C}$ for the different BCPs are presented in Figure 3. The SAXS analysis confirmed the ability of these BCPs to form segregated structures in the bulk, provided $M_{\mathrm{n}}$ is high enough. For $\mathrm{PBL}_{37}-b-\mathrm{PBD}_{65}-b-\mathrm{PBL}_{37}$, a series of peaks at scattering wavevectors indexed as $q / q^{*}$ $=1,2,3$ is clearly visible which is consistent with a lamellar mesostructure with a periodicity of $10.5 \mathrm{~nm} . \mathrm{PBL}_{75}-b-\mathrm{PBD}_{65}-b-\mathrm{PBL}_{75}$ exhibits a SAXS pattern characteristic of a hexagonally packed 
cylindrical morphology with a periodicity of $14.7 \mathrm{~nm}$, as indicated by the $1, \sqrt{3}, 4, \sqrt{ } 7$ and $\sqrt{ } 9$ peaks scattering ratios (Figure 3a). These morphological assignments are in accordance with the BCP composition determined from ${ }^{1} \mathrm{H}-\mathrm{NMR}$ (Table 1). Further temperature-dependent SAXS experiments have been performed on PBL-containing BCPs. Figure S7a shows the SAXS profiles recorded for $\mathrm{PBL}_{37}-b-\mathrm{PBD}_{65}-b-\mathrm{PBL}_{37}$ in order to probe a potential order-order or order-disorder transitions. As the temperature reached $100^{\circ} \mathrm{C}$, higher order reflections vanished and a correlation hole scattering peak found in disordered BCP melt is apparent at $q^{*}=0.63 \mathrm{~nm}^{-1} .9,54$ For PBL75-b$\mathrm{PBD}_{65}-b-\mathrm{PBL}_{75}$, broadening of the primary peak is visible at $140^{\circ} \mathrm{C}$ (Figure $\mathrm{S} 7 \mathrm{~b}$ ), even if the $\mathrm{BCP}$ phase separated structure is still evident with higher order reflections. Such moderate orderdisorder transition temperature BCP systems could show potential in thin film BCP nanotechnology such as nanolithography due to their accelerated defect annihilation mechanisms. ${ }^{55}$

For the BCPs synthesized from the PBD H macro-initiators, two lamellar structures with periodicities of 12.1 and $13.7 \mathrm{~nm}$ (Figure 3b) were obtained from $\mathrm{PBL}_{25}-b-\mathrm{PBD} \mathrm{H}_{55}-b-\mathrm{PBL}_{25}$ and $\mathrm{PBL}_{35}-b-\mathrm{PBD} \mathrm{H}_{55}-b-\mathrm{PBL}_{35}$, respectively, while a PBD $\mathrm{H}$ hexagonally packed cylinders mesostructure $\left(\mathrm{d}=15.8 \mathrm{~nm}\right.$ ) was formed from the $\mathrm{PBL}_{54}-b-\mathrm{PBD}_{55}-b-\mathrm{PBL}_{54} \mathrm{BCP}$ of higher PBL volume fraction $\left(f_{\mathrm{BL}}=0.69\right)$. 

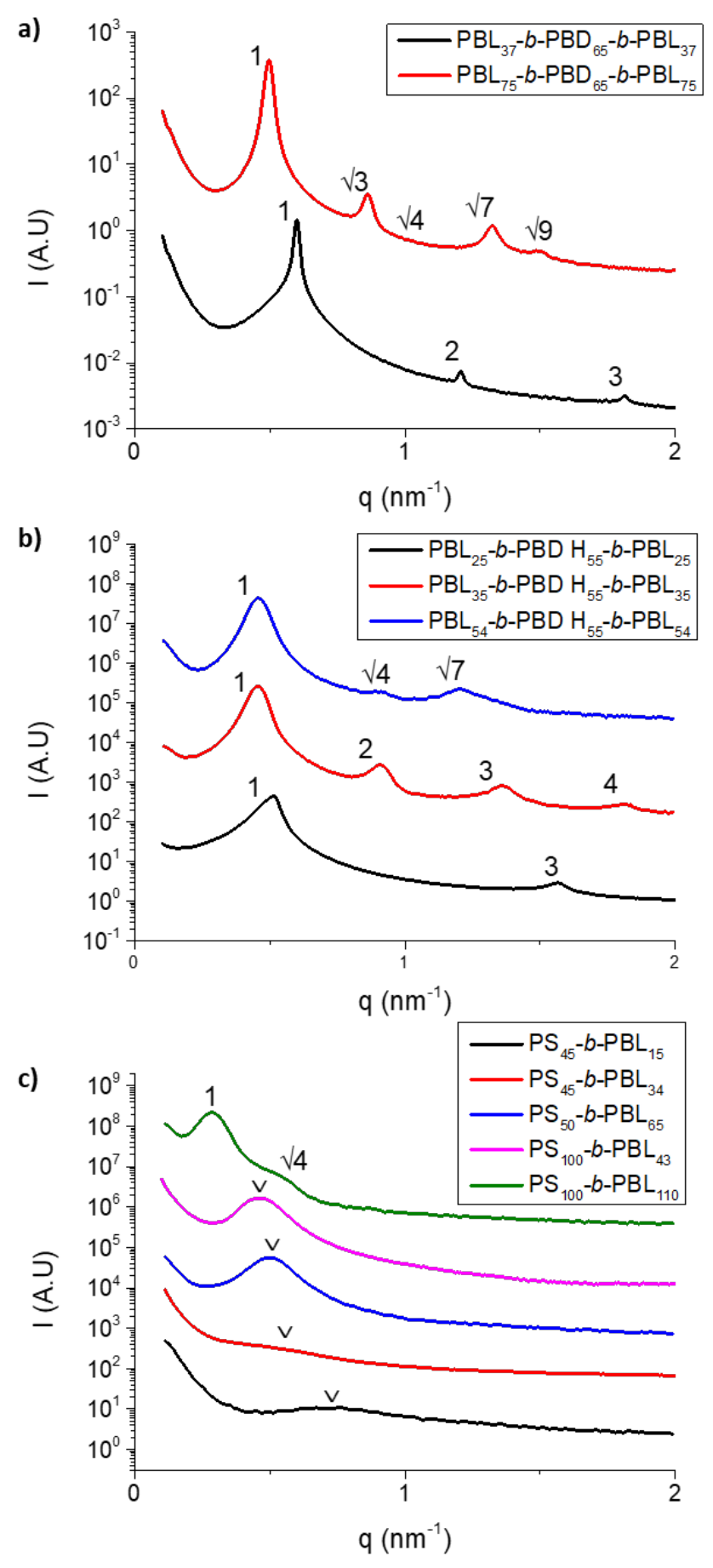

Figure 3. Representative SAXS profiles acquired at $25^{\circ} \mathrm{C}$ for PBL-containing BCP samples. (a) PBL- $b$-PBD- $b$-PBL BCPs, (b) PBL- $b$-PBD H- $b$-PBL BCPs, and (c) PS- $b$-PBL BCPs. 
The PS- $b$-PBL BCPs were also characterized by SAXS as presented in Figure 3c. For the lowest molecular weight BCPs (i.e.; $\mathrm{PS}_{45}-b-\mathrm{PBL}_{15}$ and $\mathrm{PS}_{45}-b-\mathrm{PBL}_{34}$ ), a weak correlation hole scattering signal is apparent, underlining the limited phase separation, even if two glass transition temperatures were detected in the DSC experiments. With increasing molecular weight (i.e.: PS $50^{-}$ $b$-PBL65 and $\left.\mathrm{PS}_{100}-b-\mathrm{PBL}_{43}\right)$, the SAXS profiles present clear primary scattering peaks, even if the lack of further reflections hints a poor ordering of the self-assembled structures. For PS ${ }_{100}-b$ $\mathrm{PBL}_{110}$, a higher order signal, at $q / q^{*} \approx \sqrt{4}$ clearly confirms the formation of self-assembled structure even if the poorly defined SAXS profile does not allow a clear morphological assignment.

Isochronal dynamic elastic moduli $\left(\mathrm{G}^{\prime}\right)$ measurements presented in Figure 4 were used to identify the order-disorder transition temperatures (TODT) of nearly compositionally symmetrical PBL- $b$-PBD H- $b$-PBL and PS- $b$-PBL BCPs. The TODT values were associated with the temperature at which the elastic modulus, $\mathrm{G}^{\prime}$, discontinuously decreases upon heating. For $\mathrm{PBL}_{17}-b-\mathrm{PBD}_{42}-$ $b$ - $\mathrm{PBL}_{17}$ and $\mathrm{PBL}_{25}-b-\mathrm{PBD}_{55}-b-\mathrm{PBL}_{25}$, the elastic modulus abruptly decreases above $117^{\circ} \mathrm{C}$ and $215^{\circ} \mathrm{C}$, respectively, while the drop of the elastic modulus was observed at $126^{\circ} \mathrm{C}$ and $169^{\circ} \mathrm{C}$ for $\mathrm{PS}_{50}-b-\mathrm{PBL}_{65}$ and $\mathrm{PS}_{100}-b-\mathrm{PBL}_{110}$, respectively. These values obtained for nearly symmetrical block copolymers were used to estimate the temperature-dependent Flory-Huggins parameter, $\chi(T)$, representing $\chi(T)=\frac{\alpha}{T}+\beta$ in terms of enthalpic, $\alpha$, and entropic, $\beta$, contributions. ${ }^{56}$ Random phase approximation method predicts the order-disorder transition for symmetric diblock and triblock copolymers to occur when $(\chi N)_{\mathrm{ODT}}=10.5$ and $(\chi N)_{\mathrm{ODT}}=18$, respectively. ${ }^{9,57,58}$ For the determination of the Flory-Huggins parameters, the overall degree of polymerization, $N$, was recalculated from a reference of $118 \AA^{3}$ using the room temperature densities of the homopolymers. Accordingly, the Flory-Huggins parameters, $\chi_{P B L / P B D H}$ and $\chi_{P B L / P S}$, for the PBL- $b$-PBD H- $b$-PBL and PS- $b$-PBL systems were determined as: 


$$
\chi_{P B L / P B D H}=136.0 / T-0.097 \text { and } \chi_{P B L / P S}=147.1 / T-0.291
$$

The magnitudes of $\chi$ calculated at $100^{\circ} \mathrm{C}$ for PBL/PBD $\mathrm{H}\left(\chi_{P B L / P B D H}\left(100^{\circ} \mathrm{C}\right)=0.27\right)$ and $\mathrm{PBL} / \mathrm{PS}\left(\chi_{P B L / P S}\left(100^{\circ} \mathrm{C}\right)=0.1\right)$ systems are comparable or even slightly higher than other block copolymers associating biodegradable and polyolefin blocks such as PS-b-PLA $\left(\chi_{P L A / P S}\left(100^{\circ} C\right)=0.096\right)$ and PDLLA- $b-P B D-b-P D L L A\left(\chi_{P L A / P B D}\left(100^{\circ} C\right)=0.21\right) .{ }^{27,59-62}$
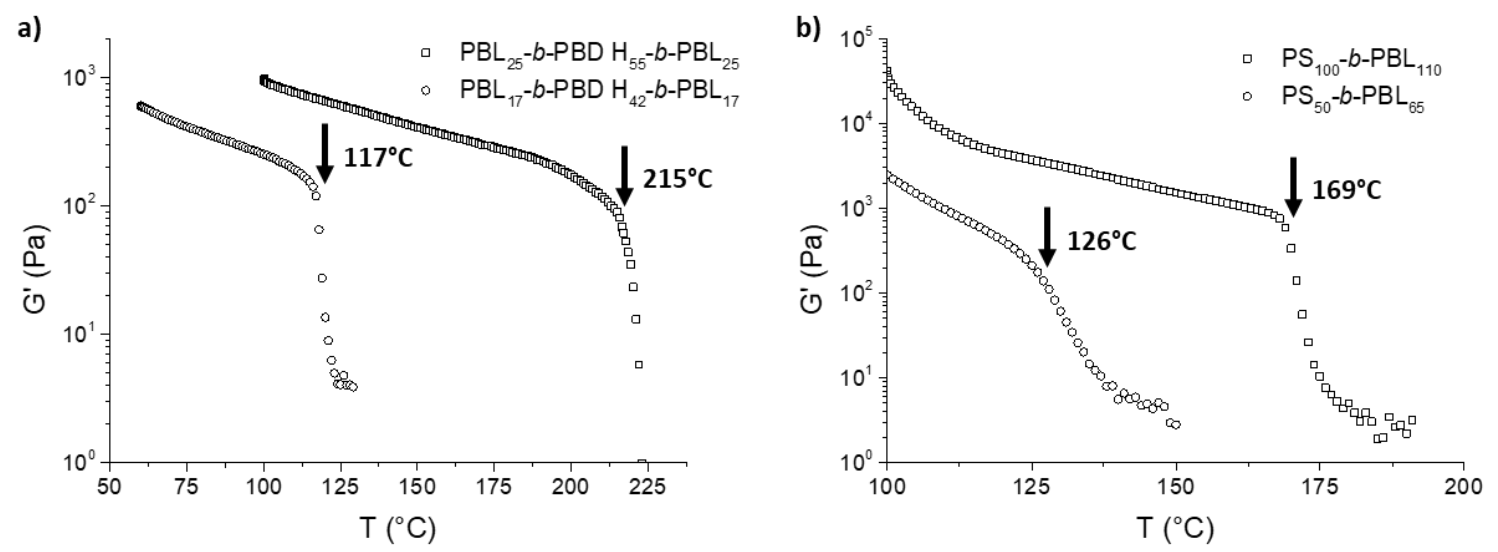

Figure 4. Isochronal temperature ramp tests upon heating for (a) PBL-b-PBD H-b-PBL triblock and (b) PS- $b$-PBL diblock copolymers. The ODT onset is marked by an arrow.

Microphase segregation in the thin film state. Thin film self-assembling properties were also probed for these PBL-containing BCPs with a focus on the cylinder-forming materials. Thin films were prepared on silicon substrates by spin-coating of $1 \mathrm{wt} \%$ BCP solutions in a PGEMA/THF mixture (50:50) followed by a thermal annealing treatment above the glass transition temperature of the materials. Additionally, a short plasma treatment was used to enhance the contrast between the BCP domains. Figure 5 shows the resulting mesostructures for $\mathrm{PBL}_{75}-b-\mathrm{PBD}_{65}-b-\mathrm{PBL}_{75}$, $\mathrm{PBL}_{54}-b-\mathrm{PBD} \mathrm{H}_{55}-b-\mathrm{PBL}_{54}$ and $\mathrm{PS}_{100}-b$-PBL 43 . In accordance with the SAXS characterization, PBD cylinders with an in-plane orientation (cylinder-to-cylinder distance of $13 \mathrm{~nm}$ ) were produced 
from $\mathrm{PBL}_{75}-b-\mathrm{PBD}_{65}-\mathrm{b}-\mathrm{PBL} 75$ as observed on the SEM image presented in Figure 5a. A similar observation was made by AFM (Figure $5 b$ ) for the $\mathrm{PBL}_{54}-b$-PBD $\mathrm{H}_{55}-b-\mathrm{PBL}_{54}$ nanostructured thin film, where PBD cylinders lying parallel to the surface (cylinder-to-cylinder distance of $15.2 \mathrm{~nm}$ ) are obtained after thermal annealing. Since the substrates were not modified by non-preferential polymer layers, ${ }^{63,64}$ in-plane orientation of the cylinder-forming BCPs is expected to be more favorable than out-of-plane orientation considering the surface energy difference between the BCP domains. Despite of the poorly defined SAXS profile (Figure 3c), $\mathrm{PS}_{100}-b$-PBL43 exhibits a segregated morphology in thin film as shown in Figure 5c, which could be tentatively assigned to PBL spheres taking into account the BCP composition. Attempts to visualize the self-assembled structures by AFM or SEM for the BCPs forming a lamellar morphology in the bulk did not lead to conclusive results, as an in-plane lamellar orientation driven by the surface energy mismatch between the two BCP domains is most probably obtained after the thermal annealing. To support this assertion, Figure S8 shows a thermally annealed $\mathrm{PBL}_{25}-b-\mathrm{PBD}_{55}-b-\mathrm{PBL}_{25}$ thin film where steps of $c a .10 \mathrm{~nm}$ can be observed between the terraces, in good agreement with the bulk BCP periodicity. ${ }^{65-67}$ As the substrate and surface were not modified, the parallel orientation is more favorable than perpendicular orientation for cylindrical and lamellar morphologies.
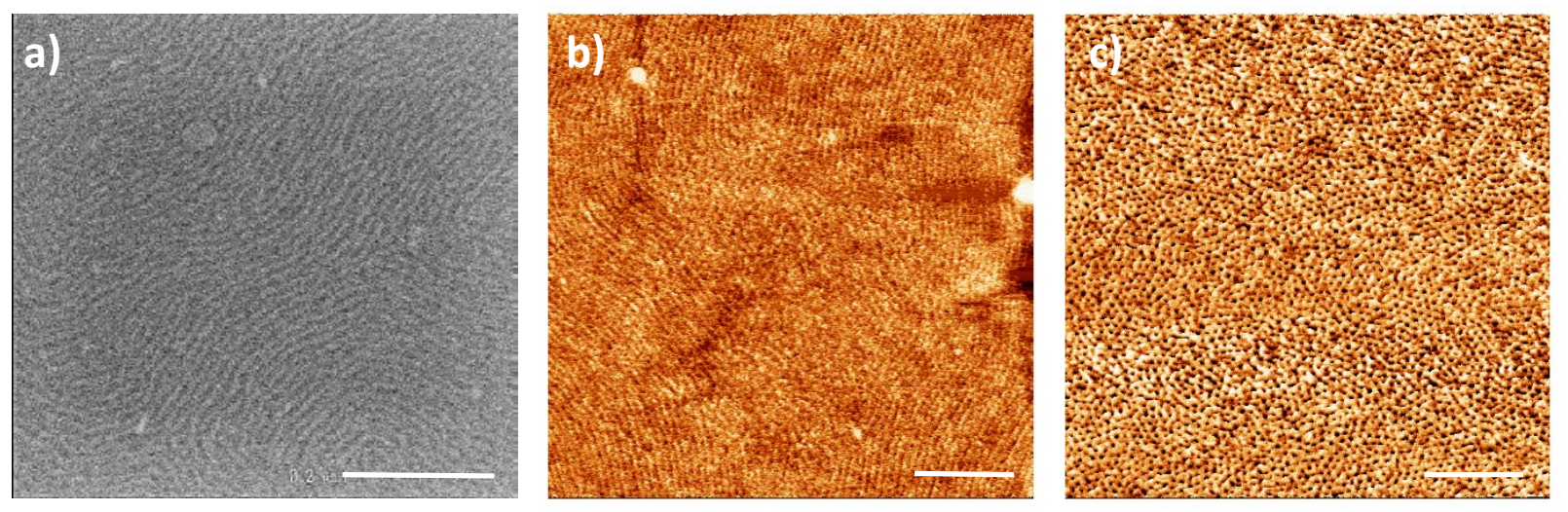
Figure 5. Thin film morphologies of selected PBL-containing BCPs. (a) SEM image of a thin film of PBL75- $b-\mathrm{PBD}_{65}-b-\mathrm{PBL}_{75}$ annealed at $120^{\circ} \mathrm{C}$ during $10 \mathrm{~min}$, (b) AFM phase image of a thin film of PBL54- $b$-PBD $\mathrm{H}_{55}-b$-PBL54 annealed at $120^{\circ} \mathrm{C}$ during 10 min, and (c) AFM phase image of a $\mathrm{PS}_{100}-b-\mathrm{PBL}_{43}$ thin film annealed at $100^{\circ} \mathrm{C}$ during 4 h. Scale: $200 \mathrm{~nm}$.

In conclusion, the results reported here showcase the efficiency of organocatalyzed ROP to prepare PBL-containing BCPs of well-defined structures. Tri- and di-block copolymers of wellcontrolled molar masses and narrow molar distributions were prepared by HOTf-organocatalyzed ROP of $\beta$-BL using mono- and di-hydroxylated macro-initiators (PS, PBD and PBD H, respectively). In addition, these BCPs were found to segregate in lamellae, cylinders or spheres with sub-20 nm periodicities and the estimated $\chi$ values are comparable or even higher than those reported for other BCPs associating biodegradable and polyolefin blocks. This is the first time PBL-containing block copolymers are shown to self-assemble at such low periodicities. These results contribute to broaden the structural diversity of "high” $\chi$ BCPs containing a biodegradable block.

\section{ASSOCIATED CONTENT}

Supporting Information. Electronic Supplementary Information (ESI) available: Experimental procedures for the polymer preparation and analytical data, TGA traces, SEC traces and temperature-dependent SAXS profiles. This material is available free of charge via the Internet at http://pubs.acs.org.

\section{AUTHOR INFORMATION}

\section{Corresponding Author}


*bmv@chimie.ups-tlse.fr

*dbouriss@chimie.ups-tlse.fr

\section{Author Contributions}

The manuscript was written through contributions of all authors. All authors have given approval to the final version of the manuscript.

\section{ORCID}

Didier Bourissou: 0000-0002-0249-1769

Blanca Martin Vaca: 0000-0002-3822-0645

\section{Notes}

The authors declare no competing financial interest.

\section{ACKNOWLEDGMENT}

This work was supported financially by the Centre National de la Recherche Scientifique, the Université de Toulouse and ARKEMA. F. K. acknowledges the French "Ministère de l'Enseignement Supérieur, de la Recherche et de l'Innovation » for CIFRE funding. G. F. acknowledges the help of the Equipex ELORPrintTec (ANR-10-EQPX-28-01) and the LCPOArkema industrial chair "HOMERIC” (ANR-13-CHIN-0002-01). The ESRF is acknowledged for allocating beamtime at the Dutch-Belgian (DUBBLE) and D2AM French Beamlines for the SAXS experiments. Dr X. Chevalier (ARKEMA) is kindly acknowledged for the SEM analyses. 


\section{REFERENCES}

(1) Kim, H.-C. C.; Park, S.-M. M.; Hinsberg, W. D.; Division, I. R. Chem. Rev. 2010, 110 (1), 146-177.

(2) Mai, Y.; Eisenberg, A. Chem. Soc. Rev. 2012, 41 (18), 5969.

(3) Bates, C. M.; Bates, F. S. Macromolecules 2017, 50 (1), 3-22.

(4) Spinelli, H. J. Adv. Mater. 1998, 10 (15), 1215-1218.

(5) Jackson, E. A.; Hillmyer, M. A. ACS Nano 2010, 4 (7), 3548-3553.

(6) Darling, S. B. Energy Environ. Sci. 2009, 2 (12), 1266.

(7) Stoykovich, M. P.; Kang, H.; Daoulas, K. C.; Liu, G.; Liu, C.; de Pablo, J. J.; Müller, M.; Nealey, P. F. ACS Nano 2007, 1 (3), 168-175.

(8) Gu, X.; Gunkel, I.; Russell, T. P. Philos. Trans. R. Soc. A Math. Phys. Eng. Sci. 2013, 371 (2000), 20120306-20120306.

(9) Leibler, L. Macromolecules 1980, 13 (6), 1602-1617.

(10) Matsen, M. W.; Bates, F. S. Macromolecules 1996, 29 (4), 1091-1098.

(11) Semenov, A. N. Sov. Phys. JETP 1985, 61 (4), 733-742.

(12) Sinturel, C.; Bates, F. S.; Hillmyer, M. A. ACS Macro Lett. 2015, 4 (9), 1044-1050.

(13) Jeong, S.-J.; Kim, J. Y.; Kim, B. H.; Moon, H.-S.; Kim, S. O. Mater. Today 2013, 16 (12), 468-476.

(14) Zhao, Y.; Sivaniah, E.; Hashimoto, T. Macromolecules 2008, 41 (24), 9948-9951.

(15) Miquelard-Garnier, G.; Roland, S. Eur. Polym. J. 2016, 84, 111-124.

(16) Aissou, K.; Mumtaz, M.; Fleury, G.; Portale, G.; Navarro, C.; Cloutet, E.; Brochon, C.; Ross, C. A.; Hadziioannou, G. Adv. Mater. 2015, 27 (2), 261-265.

(17) Durand, W. J.; Blachut, G.; Maher, M. J.; Sirard, S.; Tein, S.; Carlson, M. C.; Asano, Y.; Zhou, S. X.; Lane, A. P.; Bates, C. M.; Ellison, C. J.; Willson, C. G. J. Polym. Sci. Part A Polym. Chem. 2015, 53 (2), 344-352.

(18) Rho, Y.; Aissou, K.; Mumtaz, M.; Kwon, W.; Pécastaings, G.; Mocuta, C.; Stanecu, S.; Cloutet, E.; Brochon, C.; Fleury, G.; Hadziioannou, G. Small 2015, 11 (48), 6377-6383.

(19) Kennemur, J. G.; Yao, L.; Bates, F. S.; Hillmyer, M. A. Macromolecules 2014, 47 (4), 1411-1418.

(20) van Genabeek, B.; de Waal, B. F. M.; Gosens, M. M. J.; Pitet, L. M.; Palmans, A. R. A.; Meijer, E. W. J. Am. Chem. Soc. 2016, 138 (12), 4210-4218. 
(21) Jeong, G.; Yu, D. M.; Mapas, J. K. D.; Sun, Z.; Rzayev, J.; Russell, T. P. Macromolecules 2017, 50 (18), 7148-7154.

(22) Luo, Y.; Montarnal, D.; Kim, S.; Shi, W.; Barteau, K. P.; Pester, C. W.; Hustad, P. D.; Christianson, M. D.; Fredrickson, G. H.; Kramer, E. J.; Hawker, C. J. Macromolecules 2015, 48 (11), 3422-3430.

(23) Lee, J. G.; Jung, Y. S.; Han, S.-H.; Kim, K.-M.; Han, Y.-K. Adv. Mater. 2014, 73, 1-7.

(24) Kwak, J.; Mishra, A. K.; Lee, J.; Lee, K. S.; Choi, C.; Maiti, S.; Kim, M.; Kim, J. K. Macromolecules 2017, 50 (17), 6813-6818.

(25) Rodwogin, M. D.; Spanjers, C. S.; Leighton, C.; Hillmyer, M. A. ACS Nano 2010, 4 (2), 725-732.

(26) Schmidt, S. C.; Hillmyer, M. A. Macromolecules 1999, 32 (15), 4794-4801.

(27) Schmidt, S. C.; Hillmyer, M. A. J. Polym. Sci. Part B Polym. Phys. 2002, 40 (20), 23642376.

(28) Zalusky, A. S.; Olayo-Valles, R.; Taylor, C. J.; Hillmyer, M. A. J. Am. Chem. Soc. 2001, 123 (7), 1519-1520.

(29) Cushen, J. D.; Bates, C. M.; Rausch, E. L.; Dean, L. M.; Zhou, S. X.; Willson, C. G.; Ellison, C. J. Macromolecules 2012, 45 (21), 8722-8728.

(30) Wolf, J. H.; Hillmyer, M. A. Langmuir 2003, 19 (16), 6553-6560.

(31) Lee, I.; Panthani, T. R.; Bates, F. S. Macromolecules 2013, 46 (18), 7387-7398.

(32) Panthani, T. R.; Bates, F. S. Macromolecules 2015, 48 (13), 4529-4540.

(33) Vora, A.; Wojtecki, R. J.; Schmidt, K.; Chunder, A.; Cheng, J. Y.; Nelson, A.; Sanders, D. P. Polym. Chem. 2016, 7 (4), 940-950.

(34) Yang, G.-W.; Wu, G.-P.; Chen, X.; Xiong, S.; Arges, C. G.; Ji, S.; Nealey, P. F.; Lu, X.-B.; Darensbourg, D. J.; Xu, Z.-K. Nano Lett. 2017, 17 (2), 1233-1239.

(35) Pitet, L. M.; Wuister, S. F.; Peeters, E.; Kramer, E. J.; Hawker, C. J.; Meijer, E. W. Macromolecules 2013, 46 (20), 8289-8295.

(36) Vora, A.; Alva, G.; Chunder, A.; Schmidt, K.; Magbitang, T.; Lofano, E.; Arellano, N.; Cheng, J.; Sanders, D. P. J. Photopolym. Sci. Technol. 2016, 29 (5), 685-688.

(37) Chen, G.-Q. Chem. Soc. Rev. 2009, 38 (8), 2434.

(38) Carpentier, J.-F. Macromol. Rapid Commun. 2010, 31 (19), 1696-1705.

(39) Aluthge, D. C.; Xu, C.; Othman, N.; Noroozi, N.; Hatzikiriakos, S. G.; Mehrkhodavandi, P. Macromolecules 2013, 46 (10), 3965-3974.

(40) Kurcok, P.; Dubois, P.; Sikorska, W.; Jedliñski, Z.; Jérôme, R. Macromolecules 1997, 30 
(19), 5591-5595.

(41) Townsend, K. J.; Busse, K.; Kressler, J.; Scholz, C. Biotechnol. Prog. 2008, 21 (3), 959964.

(42) Abdelwahab, M. A.; Martinelli, E.; Alderighi, M.; Grillo Fernandes, E.; Imam, S.; Morelli, A.; Chiellini, E. J. Polym. Sci. Part A Polym. Chem. 2012, 50 (24), 5151-5160.

(43) Lynd, N. A.; Meuler, A. J.; Hillmyer, M. A. Prog. Polym. Sci. 2008, 33 (9), 875-893.

(44) Widin, J. M.; Schmitt, A. K.; Schmitt, A. L.; Im, K.; Mahanthappa, M. K. J. Am. Chem. Soc. 2012, 134 (8), 3834-3844.

(45) Kiesewetter, M. K.; Shin, E. J.; Hedrick, J. L.; Waymouth, R. M. Macromolecules 2010, 43 (5), 2093-2107.

(46) Ottou, W. N.; Sardon, H.; Mecerreyes, D.; Vignolle, J.; Taton, D. Prog. Polym. Sci. 2016, 56, 64-115.

(47) Hu, S.; Zhao, J.; Zhang, G.; Schlaad, H. Prog. Polym. Sci. 2017, 74, 34-77.

(48) Jaffredo, C. G.; Carpentier, J.-F.; Guillaume, S. M. Polym. Chem. 2013, 4 (13), 3837.

(49) Couffin, A.; Martín-Vaca, B.; Bourissou, D.; Navarro, C. Polym. Chem. 2014, 5 (1), 161168.

(50) Aoyagi, Y.; Yamashita, K.; Doi, Y. Polym. Degrad. Stab. 2002, 76 (1), 53-59.

(51) Kikkawa, Y.; Suzuki, T.; Tsuge, T.; Kanesato, M.; Doi, Y.; Abe, H. Biomacromolecules 2006, 7 (6), 1921-1928.

(52) Santangelo, P. G.; Roland, C. M. Macromolecules 1998, 31 (14), 4581-4585.

(53) Morèse-Séguéla, B.; St-Jacques, M.; Renaud, J. M.; Prod'homme, J. Macromolecules 1980, 13 (1), 100-106.

(54) Almdal, K.; Rosedale, J. H.; Bates, F. S.; Wignall, G. D.; Fredrickson, G. H. Phys. Rev. Lett. 1990, 65 (9), 1112-1115.

(55) Li, W.; Nealey, P. F.; de Pablo, J. J.; Müller, M. Phys. Rev. Lett. 2014, 113 (16), 168301.

(56) Russell, T. P.; Hjelm, R. P.; Seeger, P. A. Macromolecules 1990, 23 (3), 890-893.

(57) Mayes, A. M.; Olvera De La Cruz, M. J. Chem. Phys. 1989, 91 (11), 7228-7235.

(58) Wu, L.; Cochran, E. W.; Lodge, T. P.; Bates, F. S. Macromolecules 2004, 37 (9), 33603368.

(59) Zalusky, A. S.; Olayo-Valles, R.; Wolf, J. H.; Hillmyer, M. A. J. Am. Chem. Soc. 2002, 124 (43), 12761-12773.

(60) Martello, M. T.; Hillmyer, M. A. Macromolecules 2011, 44 (21), 8537-8545. 
(61) Lee, I.; Panthani, T. R.; Bates, F. S. Macromolecules 2013, 46 (18), 7387-7398.

(62) Zhang, X.; He, Q.; Chen, Q.; Nealey, P. F.; Ji, S. ACS Macro Lett. 2018, 7 (6), 751-756.

(63) Mansky, P.; Lui, Y.; Huang, E.; Russell, T. P.; Hawker, C. J. Science (80-. ). 1997, 275 (5305), 1458-1460.

(64) Han, E.; Stuen, K. O.; Leolukman, M.; Liu, C.-C.; Nealey, P. F.; Gopalan, P. Macromolecules 2009, 42 (13), 4896-4901.

(65) Russell, T. P.; Coulon, G.; Deline, V. R.; Miller, D. C. Macromolecules 1989, 22 (12), 4600-4606.

(66) Coulon, G.; Collin, B.; Ausserre, D.; Chatenay, D.; Russell, T. P. J. Phys. 1990, 51 (24), 2801-2811.

(67) Maher, M. J.; Bates, C. M.; Blachut, G.; Sirard, S.; Self, J. L.; Carlson, M. C.; Dean, L. M.; Cushen, J. D.; Durand, W. J.; Hayes, C. O.; Ellison, C. J.; Willson, C. G. Chem. Mater. 2014, 26 (3), 1471-1479. 
"for Table of Contents use only"

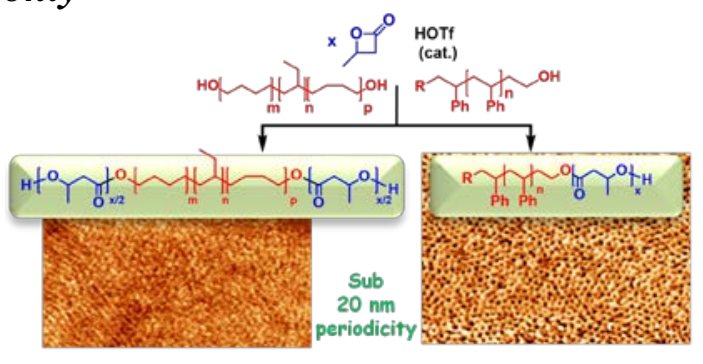

